\title{
Impacts of contaminant sources on marine fish abundance and species richness: a review and meta-analysis of evidence from the field
}

\author{
Andrew McKinley*, Emma L. Johnston \\ Evolution \& Ecology Research Centre, School of Biological, Earth and Environmental Sciences, \\ University of New South Wales, Sydney, New South Wales 2052, Australia
}

\begin{abstract}
We conducted a systematic review and meta-analysis of the in situ effects of contaminant sources on fish abundance and species richness. We discuss these effects and examine the role of contaminant sources, habitats, and study systems. We also highlight the role of fish ecology in determining contaminant impacts, mechanisms of impact, and areas for future research. A total of 45 papers were analyzed in the meta-analysis, which revealed that the average change in abundance at contaminated sites was $+103 \times$ (fish farms), $+40 \%$ (sewage studies), $-52 \%$ (industrial effluent), and $-65 \%$ (run-off). This analysis suggested that the abundance of fish assemblages in coral reefs was negatively impacted by contaminants and that these reefs are more sensitive than other habitats. Weak trends were observed for species richness, which may suggest that contamination is not having an impact on fish diversity. Some sources of contamination that are also sources of food are having sizeable effects on abundance and richness and are likely to be of commercial and environmental significance. Further research is warranted, particularly where contamination may act as an additional stressor in impacted communities.
\end{abstract}

KEY WORDS: Marine contamination · Abundance and richness of fish

\section{INTRODUCTION}

Many marine fish species have experienced both rapid and long-term population declines attributable to a variety of anthropogenic stressors (Pauly et al. 2002). Anthropogenic impacts on fish abundance and diversity are a significant management concern, and it is likely that shifting fish populations are driving further changes to marine ecosystems (Frank et al. 2005, Jiao 2009). The majority of scientific literature addressing declining stocks focuses on the impacts of commercial fishing on a few economically important species. Anthropogenic factors such as climate change, invasive species, habitat modification, and marine contamination are little studied within the context of changing marine fish assemblages (Rose 2000, Perry et al. 2005). These stressors may play a large and poorly understood role in structuring fish communities, and there is evidence to suggest that they may act synergistically with commercial fishing pressures in some contexts (Micheli 1999, Islam \& Tanaka 2004, Hylland 2006b, Breitburg et al. 2009).

The effects of marine contamination on fish ecology, abundance, and biodiversity have received relatively little attention in the scientific literature (Murphy et al. 2008). A great deal of research examines the physiological effects of contaminants, including their presence, biomagnification, toxicology, and biomarker induction in marine fish populations (Costello \& Read 1994, Wirgin \& Waldman 1998, Austin 1999, van der Oost et al. 2003, Hylland 2006b). Contaminants are widespread within fish populations, often at levels that could reduce growth, fecundity, or survivorship, and which may ultimately have an influence on structuring fish communities (Jones \& Reynolds 1997, Kingsford et al. 1996a, Arkoosh et al. 1998a, Robinet \& Feunteun 2002). The majority of this research addresses the issue at the genetic, cellular, chemical, or organism level, 
while comparatively little research has been done linking this information to changes in wild populations and assemblages (Rose 2000, Clements \& Rohr 2009). As a result, ecologically pertinent information regarding the impacts of contaminants on wild fish abundance, assemblage structure, ecological function, and biodiversity is lacking. This contrasts with other aquatic organisms, such as infaunal invertebrates, which are comparatively well studied within this context (Johnston \& Roberts 2009).

Review articles addressing contamination effects in fish have focused on nitrogen enrichment (Micheli 1999, Nixon \& Buckley 2002, Breitburg et al. 2009), sewage outflows (Pastorok \& Bilyard 1985, Grigg 1994), and regional impacts of contamination (Dethlefsen \& Tiews 1985, Nagai 2003, Hylland et al. 2006a). No comprehensive review examining the effects of contamination on fish abundance and diversity currently exists. Key questions remain regarding the magnitude of impacts on fish populations and diversity, which families or species are most affected, and which habitats are most vulnerable. Reliable information addressing these topics could improve management of fisheries resources and wild fish assemblages.

Many forms of contaminants are present in the marine environment with varying toxicities, and each may impact diversity and abundance differently. Contaminants such as metals are present in the natural environment at trace levels, while chemicals such as some pesticides and persistent organic pollutants (POPs) are entirely artificial compounds that do not exist naturally. Metals, polycyclic aromatic hydrocarbons (PAHs), pesticides, and POPs are contaminants that display toxicological effects in fish at some concentrations (Hylland 2006b). These contaminants can be broadly characterized as 'potentially toxic contaminants'. Other classes of contaminants such as nutrients, organic sewage, food subsidies, and thermal effluents may not be acutely toxic but instead affect the ecosystem by altering food availability or the physio-chemical conditions of the environment. These chemicals can be broadly characterized as 'enriching' or 'physiochemical contaminants'. Responses to physio-chemical alteration are not always linear, and they are known to enhance the abundance and diversity of fish in some contexts (Micheli 1999, Nixon \& Buckley 2002, Breitburg et al. 2009). It is important to note that in this review we are using the term 'contaminant' rather than 'pollutant', as it is generally accepted in the ecotoxicology literature that 'contaminants' describe chemicals added to the environment above their natural concentrations that have not necessarily been demonstrated to have a negative impact at a given concentration. By contrast, 'pollutants' are generally thought of as chemical substances that have been shown to have a negative effect at a given concentration. Thus, we have chosen the term 'contaminant', as we do not wish to imply that these chemical alterations necessarily have a significant, positive, or negative environmental impact. Instead, these terms are simply meant to describe the addition of the chemical substances discussed above, irrespective of any normative judgment of environmental impacts.

Because very few studies isolate the effects of a single contaminant class on fish, and because contamination in the natural environment usually consists of a mix of chemical inputs from a range of sources, studies are analyzed in the following meta-analysis according to broad contaminant source groups. Each of these represents a mixed range of contaminants, some of which may have positive effects for fish communities. These include fish farms, sewage outflows, nutrient run-off, and industrial effluent. These contaminant sources can be broadly characterized based on the typical mixture of chemicals that they emit. Typically, fish farms emit a mixture of fish faeces, dissolved nitrogen waste, parasite and chemical treatment baths, antifoulants, and excess fish feed (Wu et al. 1994). Fish farms are thus both a source of food subsidy/nutrient enrichment and to a lesser extent a source of traditional chemical contaminants. This does not imply that these farms necessarily have a negative or positive environmental impact (discussed in detail in 'Discussion' section 'Contaminant sources').

Both run-off and sewage outflows are highly variable contaminant sources that may simultaneously provide food subsidies, nutrient enrichment, and high concentrations of potentially toxic chemicals to marine systems. It is possible that differential responses to these contaminant sources are a result of different chemical mixtures, concentrations of high impact pollutants, or effluent treatment practices (Bishop et al. 2006b, Ribeiro et al. 2008). Industrial effluents represent another mixed contaminant source; they differ from the other contamination sources examined in this study, as they contain comparatively few food subsidies and nutrients while potentially toxic contaminants are often present (such as metals and pesticides) (Costello \& Read 1994, Austin 1999, Hylland 2006b).

It is likely that fish living in some marine habitats are more susceptible to contamination than others. Habitats such as seagrasses and coral reefs are known to be highly sensitive to changing environmental conditions and contamination; this sensitivity may mean that fish that are closely associated with these habitats are disproportionately affected by contaminants (Pastorok \& Bilyard 1985, Fabricius 2005b, Deegan et al. 2007). Similarly, habitats are subject to varying levels of contaminant exposure, and those that are situated closer to contamination sources are normally exposed 
to higher levels of contaminants than those further away. The amount of water flow or flushing in a habitat is also a significant determinant of contamination exposure. Ecosystems in shallow protected waters that are poorly flushed are more likely to accumulate and retain higher concentrations of contaminants than habitats that are well flushed, in deeper water, or offshore (Roberts et al. 2010). In this meta-analysis studies have been broadly categorized according to habitat types including bare sediment, coral reefs, rocky reef and rocky bottom, and vegetated habitats. Bare sediment habitats are areas in which vegetation and hard substrate are mostly absent and the bottom is characterized primarily by sand, mud, or silt. These habitats may occur in shallow or deep waters; they can be poorly or well flushed depending on where they occur. Contaminants preferentially bind to fine sediments and are a common environmental concern in soft sediment habitats from anthropogenically modified harbors (Knott et al. 2009). Coral reefs are primarily tropical and sub-tropical environments where habitat-forming colonial polyps have created a hard substrate environment. These areas have high fish diversity and typically occur in shallow, nutrient-poor waters. Rocky reefs and rocky bottom habitats typically occur in shallow near shore waters and are high energy environments that are well flushed. Lastly, vegetated habitats include seagrass beds, kelp forests, mangrove creeks, and other areas containing habitat forming plant species. Most of these vegetative communities grow in the shallow photic zone and are typically in protected to moderately protected waters. In coral reef and vegetated environments, habitat-forming organisms may be affected first by contaminants, and changes in their communities may impact fish indirectly (discussed in more detail in 'Discussion' section 'Study systems and habitat mediation') (Deegan et al. 2002, Reopanichkul et al. 2009).

Here, we present the results of a systematic literature review and meta-analysis in which we address 4 questions about contaminant impacts on fish abundance and species richness: (1) In which habitats are researchers typically assessing the effects of contaminants on fish abundance and species richness? (2) Do marine habitats vary in their susceptibility to the impacts of contamination? (3) Do different contaminant sources vary in their ability to impact fish abundance and species richness? (4) Are some fish families or functional groups more susceptible to contamination than others?

\section{MATERIALS AND METHODS}

Search methods. In order to capture a representative sample of the marine contamination literature, a systematic literature review was conducted. A list of search terms was applied in 4 major biological databases: Aquatic Sciences and Fisheries Abstracts (1971-present), Biological Abstracts (1969-2003), Current Contents (1998-present), and Web of Science (1900-present). The following search terms were used to search these databases, and results were limited to English language studies, in peer reviewed journals, that were available in full text online:

Search 1: marine* AND fish* AND (contamina* OR pollut*);

Search 2: divers * OR biodivers * OR index* OR community* OR assemblage* OR abundance* OR stock* OR population*;

Search 3: hydrocarbon* OR PAH* OR oil ${ }^{*}$ OR metal ${ }^{*}$ OR nutrient* OR sewage* OR solid waste* OR effluent* OR estrogen* OR androgen* OR thermal* OR pesticide* OR herbicide* OR brine* OR farm* OR aquaculture* .

These 3 searches were cross-referenced against one another to produce a final selection of studies. We read the abstracts of all papers that emerged from this search $(n=>1650)$. These studies were included in the meta-analysis if they contained the following elements: (1) Quantitative data on the species richness/ abundance of a fish species or assemblage. (2) A comparison of this data between contaminated and noncontaminated sites, before and after contamination, or along contamination gradients. The research design must have been appropriate for the investigation of the impacts of contamination on the species richness/ abundance data. (3) Only in situ studies placed within the context of functional natural habitats were included. Following this criteria, field surveys, field experiments, and fisheries catch studies were included, while laboratory experiments, mesocosms, or modeling studies were excluded if they did not report field data. This distinction was made because this review focuses on in situ changes to abundance and species richness.

We then examined the citation lists of papers selected in the first round and investigated any relevant studies for inclusion in the meta-analysis. In total, this process produced 45 studies $(<3 \%)$ that satisfied the above criteria for the meta-analysis portion of our study.

From these studies we extracted qualitative data on the contaminant type (where described), contaminant source, and habitat type. Due to the limited number of studies, data was clustered into broad categories according to contaminant source (fish farm, sewage, run-off, industrial effluent) and habitat type, as defined by substrate characteristics (fish farms over bare sediment, coral reef, rocky reef and rocky bottom, vegetated habitat, bare sediment). From each study, quantitative data on species richness and abundance were extracted. We then collated data on the overall 
finding of the study (reduced, increased, or no effect on abundance/richness) as concluded by the authors and calculated the effect size (see Figs. 1 \& 2). Not all studies presented data on both abundance and species richness. Studies with only one of these measures were still included in the review but were partitioned into separate analyses. Some studies did not perform formal statistical analysis of results, but because they presented information on abundance or species richness, we were still able to extract the required information.

Where abundance data was presented for individual fish species $(n=208)$, those species were characterized according to their swimming behavior and feeding pattern. These characterizations were undertaken using basic ecological information available on the website www.fishbase.org. In some cases descriptive information provided by the authors was used to characterize species. Species were divided into 3 distinct behavioral groups following the organizational system used by www.fishbase.org: demersal, benthopelagic, and pelagic-neritic/pelagic/bathypelagic. Fishes categorized as 'reef associated' were removed due to an insufficient sample size $(n=2)$. Due to a lack of sufficient information, fish could not be fully characterized by trophic level. Instead, fish were characterized into 3 broad feeding guilds that approximate trophic levels. These are herbivores and planktivores, omnivores (eating a mixture of algae, invertebrates, and some fish), and predatory fishes (eating a mixture of macroinvertebrates and fish). Fish farm data was excluded from this analysis, as the overwhelmingly positive effect of fish farms would obscure effects from other forms of contamination.

Meta-analyses. In addition to the qualitative review, we performed a quantitative meta-analysis. The metaanalysis was partitioned into 2 distinct analyses: (1) examining any studies that reported a measurement of abundance ( $\mathrm{n}=44$ ), and (2) examining any studies which reported species richness $(n=19)$.

For these meta-analyses we calculated effect sizes that were attributed to contamination. We defined the effect size as the proportional change in mean abundance/species richness between control and impacted sites (or experimental and treatment sites for field experiments). The effect size is expressed as a natural logarithm, such that $\ln$ (effect size) $=\ln$ (impacted) $\ln$ (control). All statistical analysis and graphing of results was conducted in the natural logarithm of the response variables (Hedges et al. 1999, Johnston \& Roberts 2009). In some cases, effect size data was extracted from graphs using a computerized measurement tool; these are considered estimates only.

In all cases the abundance measure was extracted that represented the greatest number of species within a community; in studies that presented abundance measurements for an entire fish community and also for individual species, families, or trophic categories, the community measurement was always selected over measurements describing smaller species groupings. However, information on the abundance response of fish families or individual species was also recorded for qualitative analysis (discussed in 'Results of metaanalysis). Due to the different ways in which studies were structured, several procedures were created to ensure consistent data extraction. Survey studies either examined abundance/richness along gradients or contrasted contaminated and non-contaminated sites. For gradient studies the effect size was calculated by taking data from the sampling locations closest to the contamination source (or the most contaminated site where contamination data was available) and contrasting it to the reference site that was furthest from the contamination source (or the least contaminated site). For studies that sampled over multiple periods (with stable contaminant conditions), data was averaged over all periods. For studies that sampled over multiple periods with increasing or decreasing contamination loads, data was extracted from the time of highest contamination and compared to the time of lowest contamination. One paper (Dempster et al. 2004) is treated throughout our review as 2 independent studies, as it presents data separately for 2 disparate geographic regions: Spain and Australia. Lastly, for studies that sampled over multiple sampling seasons but found significant results only in one season, data was extracted from the significant season. Due to the limited number of papers available for the metaanalysis, studies of adult and larval fishes were considered together. The impact of contaminants at different stages of the fish life cycle is discussed in more detail in 'Discussion' section 'Linking contaminant effects to fish ecology'. Studies examining the effects of contamination on larval fishes (ichthyoplankton) included (Gray et al. 1992, Gray 1996, 1997). Effect sizes were contrasted by habitat and contaminant source using separate 1-way analysis of variance (ANOVA) followed by post hoc Tukey's tests.

\section{RESULTS}

\section{Summary statistics}

Of the over 1650 titles and abstracts examined, a total of 45 studies fulfilled the criteria for inclusion in the meta-analysis (Appendix 1). The majority of studies was conducted in highly developed nations (87\%) while a minority was undertaken in developing countries $(13 \%)$. Studies were clustered regionally with the majority of studies occurring in Europe (38\%), Aus- 
tralia (26\%), and North America (21\%). A minority of studies was conducted in other regions including the Caribbean (4\%), Middle East (4\%) and East Asia/ Pacific $(6 \%)$. The countries with the greatest proportion of studies were Australia (26\%), USA (including Hawaii) (19\%), Sweden (13\%), and Spain (including Canary Islands) (11\%). Limiting search results to studies published in English may have resulted in the exclusion of a significant body of literature published in other languages. The latitude of sampling was biased towards mid-latitude research sites, with $60 \%$ of studies occurring between 31 and $50^{\circ} \mathrm{N}$ or S. Studies at high latitude $+51^{\circ} \mathrm{N}$ or $\mathrm{S}(19 \%)$ and low latitude 0 to $30^{\circ} \mathrm{N}$ or $\mathrm{S}(21 \%)$ were less represented in the data set. The average maximum spatial scale (defined as the largest distance between an impacted and control site) was $53.9 \mathrm{~km}$, while the largest study was conducted over a spatial scale of approximately $600 \mathrm{~km}$. The average minimum sampling depth was $12.5 \mathrm{~m}$, while the average maximum sampling depth was $30.7 \mathrm{~m}$. Only 5 studies sampled in water $>40 \mathrm{~m}$ deep, and only 2 sampled in water $>80 \mathrm{~m}$ deep.

The greatest number of studies were conducted over bare sediment $(25 \%)$, while vegetated habitats, coral reefs, fish farms over bare sediment, and rocky bottom and rocky reef systems were roughly equal ( 15 to $20 \%$ each). No single contaminant source dominated the re-

a) Total abundance response by contaminant source

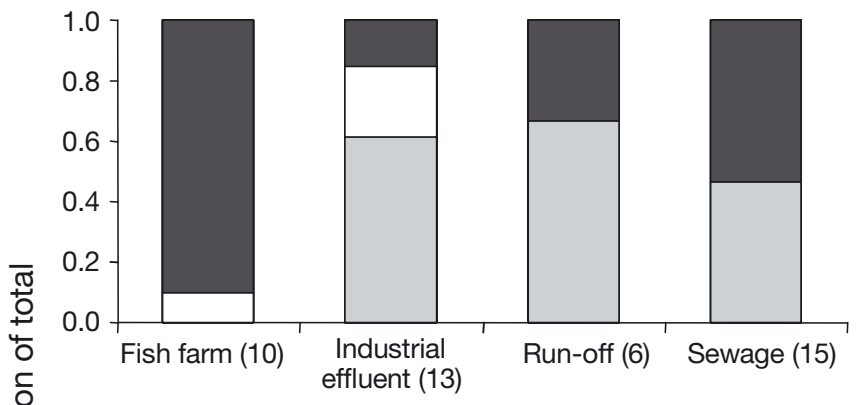

c) Total abundance response by study system

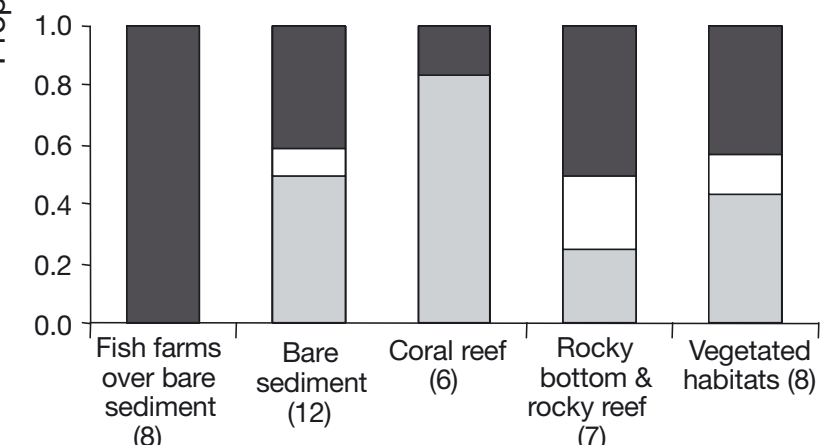

$\square$ Decreased total abundance $\square$ No change $\square$ Increased total abundance view, though urban sewage (36\%) was most studied followed by industrial effluents $(28 \%)$, fish farms $(21 \%)$, and run-off (15\%). The vast majority of studies consisted of field surveys (91\%), while fisheries catch studies and field experiments were each $\sim 5 \%$. The small number of field experiments is likely due to the comparatively high cost, as well as practical and ethical difficulty of conducting such investigations with fish.

Responses by contaminant source were variable, with the majority of fish farm studies (90\%) reporting increased abundance and richness, while the majority of industrial effluent (62\%) and run-off (67\%) studies reported negative abundance responses. Sewage studies reported negative and positive responses equally for both abundance and richness (Fig. 1). Fish farms over bare sediment were separated from other bare sediment studies due to the large difference in the magnitude and direction of reported responses. Responses by habitat type were similarly variable (Fig. 1). Of the studies reviewed, a minority reported no detectable effects of contamination upon abundance $(9 \%)$ and richness $(11 \%)$, suggesting a possible bias towards publishing research that yields statistically significant results. The ecological impacts of marine contamination may be overestimated due to the tendency of journals to publish studies which find significant results (Browman 1999).

\section{b) Species richness response by contaminant source}

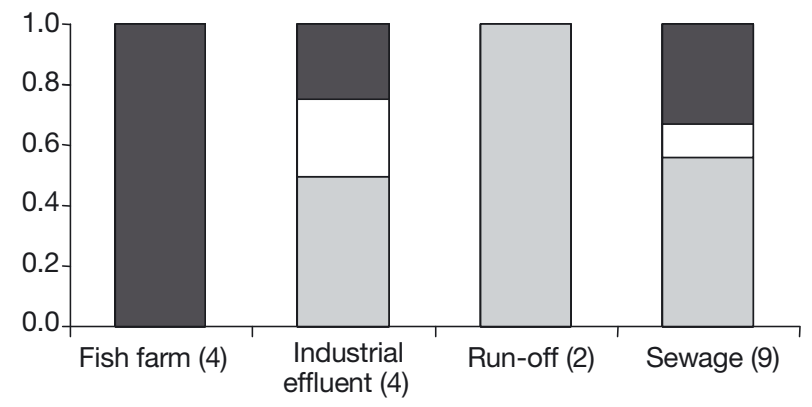

d) Species richness response by study system

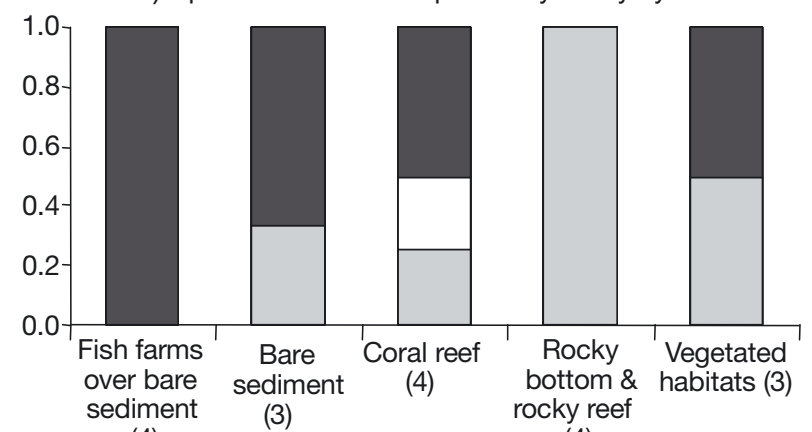

(4)

(4)

$\square$ Decreased species richness $\square$ No change $\quad \square$ Increased species richness

Fig. 1. Proportion of studies in the marine contamination literature concluding that contamination has negative, positive, or no effect on abundance and richness. The number of research papers in each category is shown in parentheses 


\section{Results of meta-analysis}

The meta-analysis supported the qualitative assessment; abundance and species richness responses to contamination were variable both for contaminant sources and sampling habitats. Among contaminant sources, the greatest effect sizes for abundance were observed among fish farms, which displayed a significant trend of increased abundance (Fig. 2a, Table 1). The effect sizes for industrial effluent and run-off displayed slight trends towards decreased abundance, and sewage appeared to show little change on average. While the effect sizes for these categories showed little change on average, this obscures the fact that the majority of studies in both categories reported negative responses to contamination (Fig. 1). The average change in abundance at contaminated sites was $+103 \times$

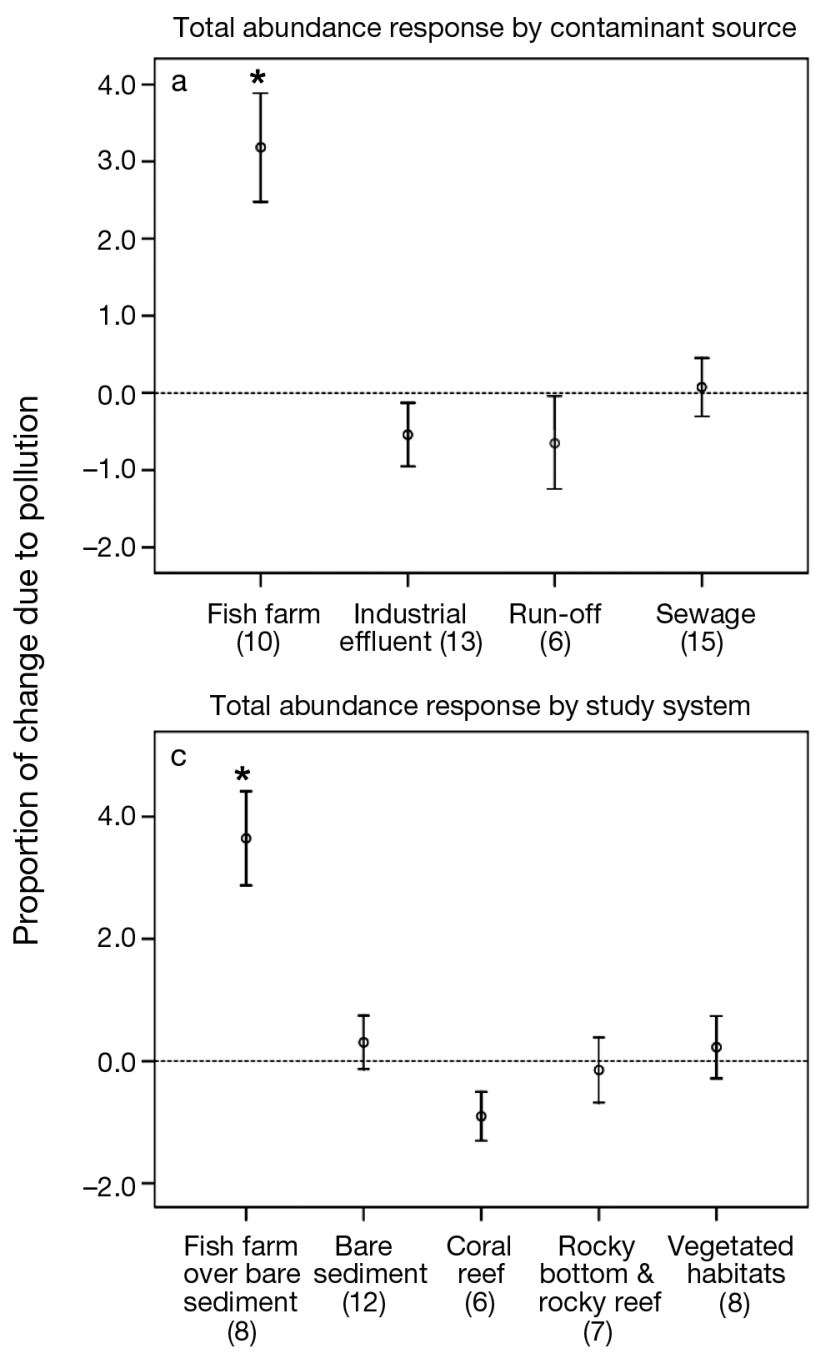

(fish farms), $+40 \%$ (sewage studies), $-52 \%$ (industrial effluent), and $-65 \%$ (run-off). While the variation between groups was significant $(p=0.000)$, Tukey's post hoc analysis indicated that this variation was due to the difference between fish farms and the other 3 groups. Sewage, industrial effluent, and run-off were a

Table 1. Analysis of variance contrasting impacts of contamination on abundance and species richness

\begin{tabular}{|lccccccccc|}
\hline & \multicolumn{4}{c}{ Effect on abundance } & \multicolumn{4}{c|}{ Effect on richness } \\
& df & MS & $F$ & $p$ & df & MS & $F$ & $p$ \\
\hline $\begin{array}{l}\text { Contam- } \\
\text { inant }\end{array}$ & 3 & 32.144 & 11.513 & 0.000 & 3 & 2.638 & 5.617 & 0.009 \\
$\begin{array}{l}\text { Study } \\
\text { system }\end{array}$ & 4 & 23.340 & 9.386 & 0.000 & 4 & 1.623 & 3.804 & 0.029 \\
\hline
\end{tabular}
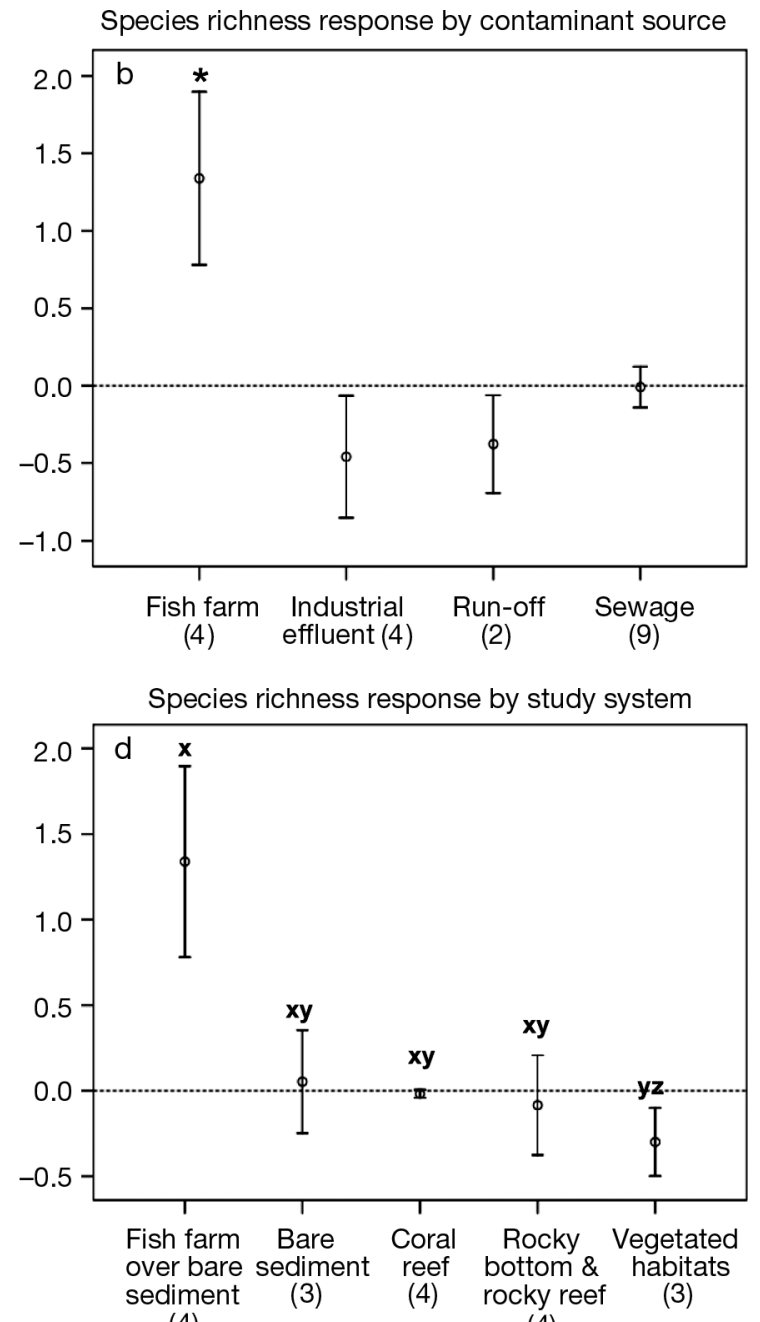

(4)

Fig. 2. (a) Total abundance response and (b) species richness response by contaminant source. (c) Total abundance response and (d) species richness response by study system. ${ }^{*}$ Category is significantly different from all other categories $(p<0.05)$. $x-y z$ pairings are significantly different $(\mathrm{p}<0.05)$. All other pairings are homogenous. Error bars are \pm 1 SE. Note that effect sizes are expressed as a natural logarithm. Other details as in Fig. 1 
homogenous subset (Fig. 2a). For the species richness analysis, the greatest effect sizes were again observed for fish farms, which displayed a significant trend of increased species richness (Fig. 2b, Table 1). Industrial effluent and run-off displayed slight trends towards decreased species richness and sewage appeared to show little change on average. The average change in species richness at contaminated sites was $+56 \%$ (fish farms), $+6 \%$ (sewage studies), $-29 \%$ (industrial effluent), and $-8 \%$ (run-off). While the variation between groups was significant $(\mathrm{p}=0.009)$, Tukey's post hoc analysis indicated that this variation was due to the difference between fish farms and the other three groups. Sewage, industrial effluent, and run-off were a homogenous subset (Fig. 2b).

Among study systems, the greatest abundance effect sizes were observed for fish farms (over bare sediment) and coral reef habitats, which displayed positive and negative responses, respectively (Fig. 2c, Table 1). The vegetated habitats, bare sediment, and rocky bottom and rocky reef groupings did not display strong upwards or downwards trends in abundance. The average change in abundance at contaminated sites was $+106 \times$ (fish farms over bare sediment), +8\% (bare sediment), $+33 \%$ (vegetated habitats), $+1.3 \times$ (rocky reef and rocky bottom), and $-63 \%$ (coral reef). While the variation between groups was significant ( $\mathrm{p}=$ 0.000), Tukey's post-hoc analysis again indicated that this variation was due to the difference between fish farms and the other 4 groups. Bare sediment, coral reefs, rocky bottom and rocky reef, and vegetated habitats were a homogenous subset (Fig. 2c). For species richness, the greatest effect size was observed for fish farms (Fig. 2d, Table 1). Other categories did not show consistent upwards or downwards trends. The average change in species richness at contaminated sites was $+56 \%$ (fish farms over bare sediment), $+18 \%$ (rocky reef and rocky bottom), $-15 \%$ (bare sediment), $-13 \%$ (vegetated habitats), and $-2 \%$ (coral reef). While the variation between groups was significant ( $\mathrm{p}=$ 0.029), Tukey's post-hoc analysis indicated that this variation was due to the difference between fish farms over bare sediment and vegetated habitats. All other pairings were non-significant (Fig. 2d).

In addition to the data discussed thus far, other qualitative information was collected during the review. The 45 studies examined in the meta-analyses reported data that summarized the abundance or species richness responses of more than 1300 fish species (note: exact numbers are not known as not all authors reported the total number of species studied. The degree of overlap between studies is unknown as not all authors reported the names of all species investigated); on average, each study reported data for $\sim 34$ species. Of this total, abundance response data was presented for a total of 208 species individually (as opposed to being summarized within a community measurement). This data was utilized to analyze abundance responses according to swimming behavior and feeding pattern groupings. For the swimming behavior analysis, fish were classified as demersal (50), benthopelagic (28), and pelagic-neritic/pelagic/bathypelagic (16). For the feeding pattern analysis fish were characterized as planktivores (20), omnivores (25), and predators (57). Abundance responses were not found to be statistically different across all swimming behavior categories ( $p=0.751$ ) and feeding guilds ( $p=0.639)$.

\section{DISCUSSION}

Fish assemblages are responding differently to distinct sources of marine contamination. Fish farms are a substantial source of marine contamination (Wu et al. 1994), but they are also a source of fish food and habitat structure in an otherwise pelagic environment. Fish farms were consistently associated with substantial increases in fish abundance and moderate increases in species richness. Sewage is another potential source of food and contamination and was associated with positive and negative responses in equal measure. In contrast, industrial effluent and run-off were more closely associated with reports of decreased fish abundance and richness, and the average effect sizes for both of these contaminant sources was negative. Differences amongst habitats were again driven by the strong association of fish farms (all located over bare sediment) with increased fish abundance and species richness. In the absence of fish farms, there were no obvious effects of contaminants in bare sediment habitats. Fish abundance in coral reefs suggested a weaker trend towards decreased abundance but nearly no change in species richness. Our results contrast with other meta-analyses in marine systems, which have found more consistent negative effects of contaminants in abundance and diversity responses (Micheli 1999, Breitburg et al. 2009, Johnston \& Roberts 2009).

\section{Contaminant sources}

In our meta-analysis, fish farms displayed the most consistent and largest responses to contamination among study groups, and this is likely due to the special nature of the contaminants emitted by these operations. Unlike most of the other contaminant sources, fish farms can primarily be viewed as a source of food subsidies and enriching organic nutrients, while other chemicals are present in lower concentrations (Wu et al. 1994). Intuitively it can be expected that these forms 
of contamination will have a positive effect on fish abundance and possibly also diversity. In addition to the papers examined in the meta-analysis, several other studies have documented the aggregation, distribution, and general increase of fish near aquaculture facilities (Dempster et al. 2005, 2009, 2010). Several studies have also demonstrated that wild fish are eating food or captive fish from these structures, confirming that they provide food subsidies to wild populations (Fernandez-Jover et al. 2007, 2008). For example, Fernandez-Jover et al. (2008) conducted a study of the gut contents of 5 dominant taxa around fish farms in the Mediterranean, and they found that 66 to $89 \%$ of wild fish around these farms were consuming the food pellets and that they ate up to $10 \%$ of the feed input at these facilities. In the past, it has been argued that the food subsidy and nutrient enrichment effects of fish farms may be somewhat confounded by the impacts of the fish farm structure itself. Tuya et al. (2006) have contributed towards clarifying this issue by employing an advanced 'before-after control impact' (BACI) research design. In their study the authors investigated the presence of wild fish around farms before and after the closure of a farm. Throughout the study the fish farm structure remained in place, and the authors demonstrated that, in the absence of feeding, the structure has $<2 \times$ the fish of control sites. In contrast, nearby farms that remained active displayed an increase in fish abundance of approximately $50 \times$ compared to control sites. The results of this study suggest that food subsidies and nutrient enrichment play the dominant role in aggregating wild fish near farms, and that the fish farm structure has a negligible influence on this phenomenon (Tuya et al. 2006).

While most studies of fish farms have examined the localized impacts of these operations, there is some indication that aquaculture is having regional effects on fish assemblages and fisheries catches. A pioneering study by Machias et al. (2006) attempted to quantify the regional effects of aquaculture in a highly developed aquaculture region, the Aegean and Ionian seas of the eastern Mediterranean basin. Machias et al. (2006) used time series data of fisheries landings, fish farm productivity, fishing fleet activity, and environmental factors over a $17 \mathrm{yr}$ period to analyze the impacts of aquaculture development on wild fish abundance and fisheries landings. The results of their study suggest that high concentrations of aquaculture activity in an oligotrophic sea could be linked to increased fisheries landings (Machias et al. 2004, 2006). In another large scale study, Dempster et al. (2009) studied the aggregation effects of fish farms along the west coast of Norway, an area spanning more than $1500 \mathrm{~km}$. They estimated that the 1200 salmon farms operating over this range are concentrating about 12000 tonnes of wild fish in just 750 ha of coastal waters. Aggregation on such a large scale would be likely to have far reaching ecological and fisheries impacts.

Run-off and sewage outflows represent more diverse contaminant sources compared to fish farms. Both runoff and sewage outflows are highly variable contaminant sources that may simultaneously provide food subsidies, nutrient enrichment, and high concentrations of potentially toxic chemicals to marine systems. It is possible that differential responses to these contaminant sources are a result of different chemical mixtures, concentrations of high impact chemicals, or effluent treatment practices. In several cases, fish abundance was increased by these contamination sources even where a variety of toxic contaminants were present at high concentrations, and in some instances declines in commercially important species were observed following the implementation of improved water quality management (Bishop et al. 2006b, Ribeiro et al. 2008). In one such study, Ribeiro et al. (2008) investigated the impacts of improvements in sewage treatment on fish assemblages living in coastal lagoons in southern Portugal. They found that the implementation of improved sewage treatment (and subsequent declines in organic matter and nutrient concentrations) in the lagoons were associated with significantly decreased fish biomass. In particular, commercially important Mugilidae species experienced a $72 \%$ decrease in their abundance. Studies such as this suggest that in some systems the positive effects of food subsidies and nutrient enrichment are overpowering the potentially negative effects of other contaminants and that some forms of contamination may be enhancing wild fish stocks.

Negative responses to sewage outflows were also reported, chiefly in instances where primary sewage treatment was absent and potentially toxic chemical concentrations were comparatively high (Aguilar et al. 2007, Reopanichkul et al. 2009). Several authors also reported negative effects of run-off, primarily where high nutrient concentrations were causing some form of eutrophication/hypoxia. While eutrophication and associated hypoxia are relatively uncommon in open marine systems (Breitburg et al. 2009), several studies in this review reported the development of these negative feedbacks as a result of very high nutrient enrichment in enclosed marine environments (Baden et al. 1990, Nagai 2003). This was demonstrated by Oczkowski \& Nixon (2008), who studied fisheries yields in relation to nutrient enrichment over a forty year period in coastal lagoons of the Nile delta (Egypt). They found that nutrient enrichment (originating primarily from agricultural run-off) initially increased the abundance of a variety of commercial fish species, resulting in increased fisheries landings. However, a 
threshold enrichment level was eventually reached ( 100 $\mu \mathrm{M}$ dissolved inorganic nitrogen), after which fish stocks declined exponentially. The authors argued that this decline was due to nutrient induced eutrophication and that commercial fishing, pesticide build-up, increased fishing effort, and metals contamination played only minor roles in the fishery collapse. It is interesting to note that even after the development of eutrophic conditions, fish stocks remained elevated compared to pre-enrichment levels, though they were much reduced compared to their pre-eutrophication peak (Oczkowski \& Nixon 2008). Studies such as this highlight the importance of quantifying and monitoring contaminants over long periods, as ecological responses may be non-linear across concentration gradients.

While industrial effluents represent another mixed contaminant source, they differed from the other contamination sources examined in the present study as they contain comparatively few food subsidies and nutrients. The industrial effluents examined consisted primarily of pulp mill, mine, petrochemical plant, power station, and chemical plant effluents, which contain a variety of contaminants that have been shown to have toxic effects (e.g. metals and pesticides) (Costello \& Read 1994, Austin 1999, Hylland 2006b). Industrial effluent studies primarily reported a decrease in the abundance of fish, which could indicate that in the absence of nutrients and food subsidies other contaminant classes are producing a negative response. Interestingly, where increased abundances were associated with industrial effluents (Jones et al. 1996, Hoisington \& Lowe 2005) water temperature was also elevated by the effluent. It is possible that in such cases thermal outflows are attracting greater numbers of fish, masking the potentially negative effects of contaminants.

\section{Study systems and habitat mediation}

We examined the responses of fish abundance and species richness to anthropogenic contamination in relation to broad habitat classifications. In our metaanalysis, fish farms were almost always located over bare sediment and displayed the most consistent and largest responses to contamination (see section 'Results of meta-analysis'). Coral reefs were the only habitat associated with a slight trend towards reduced fish abundance. This may be due to a comparatively high contaminant sensitivity of the habitat forming organisms (corals) and/or the relatively high proportion of reef fish, which are resident specialists in coral reef environments. Because corals rely on high water clarity to conduct photosynthesis, coral reefs are known to be particularly sensitive to contamination sources (such as sewage outflows), which alter water clarity through sedimentation or nutrient induced increases in algal growth (Pastorok \& Bilyard 1985, Fabricius et al. 2005a, Fabricius 2005b).

It is interesting to note that the other habitat classifications (bare sediment, rocky bottom and rocky reef, and vegetated habitats) did not show strong trends for abundance or species richness response. This could suggest that contaminant sources or certain types of chemicals are more important in determining fish ecology impacts in these ecosystems than the characteristics of the habitat itself. Relatively little research has been undertaken examining how different habitat characteristics could be mediating or affecting contamination impacts in fish assemblages. However, 2 welldesigned studies (Deegan et al. 2002, Reopanichkul et al. 2009) have investigated effects over multiple levels of ecological organization and have demonstrated the importance of habitat as a mediator of contamination impacts.

In Reopanichkul et al. (2009), the researchers evaluated the impacts of a sewage outflow on a coral reef ecosystem in Thailand. They demonstrated that sewage outflows were simultaneously associated with increased macro-algal density, decreased hard coral cover, and significant declines in fish abundance within the coral reef environment. This study was designed to assess the role of habitat forming organisms in mediating fish declines, and it is one of few to demonstrate the cascade of ecological effects over multiple levels of biological organization. Deegan et al. (2002) also investigated the impacts of contamination across multiple levels of biological organization, though their study was situated within a temperate seagrass bed. They demonstrated that contamination had a significant impact on the macrophyte community structure, where primary production shifted from eelgrass to macroalgae with increased nutrient loading. Changes to the macrophyte community were strongly associated with declines in fish abundance and diversity. Both of these studies demonstrate the importance of habitat forming organisms as mediators of contamination impacts on fish assemblages.

\section{Species richness responses}

We observed weak species richness responses for all contaminant sources and sampling habitats. The lack of any consistent species richness response associated with contamination could suggest that contaminants are not having a major impact on marine fish diversity. However, further research is needed before such conclusions can be drawn, especially given that some 
studies reported decreases in species richness of up to $60 \%$ (Gray et al. 1992, Smith et al. 1999a). While inconsistent responses were obtained for species richness, it is possible that contamination may act to alter fish assemblages in ways that are not detected by simple diversity measurements. Several studies have shown significant changes in the abundance and trophic structure of fish assemblages, while little impact was detected by conventional diversity measures (Khalaf \& Kochzius 2002, Guidetti et al. 2003, Ribeiro et al. 2008). More complex measures of biodiversity and/or community structure, such as the Shannon-Wiener diversity index, Pielou's evenness, or taxonomic relatedness (Costello et al. 2001) may better characterize community responses to contamination than simple richness or abundance indexes (Washington 1984). However, these indices were insufficiently reported in the data set for a meta-analysis.

Better measurement methods could improve our ability to detect and understand changes to fish diversity. In an excellent study, Khalaf \& Kochzius (2002) investigated the impacts of urban and industrial contamination in a heavily developed port in the Gulf of Aqaba, Jordan. They assessed the trophic community structure of coral reef fishes near disturbed and undisturbed sites and analyzed this data using a variety of univariate and multivariate measures. Univariate measures such as species richness, diversity, and evenness detected no negative impacts of contamination. However, a multivariate analysis of species abundance (characterized according to trophic categories) clearly separated disturbed from undisturbed sites. These multivariate measures demonstrated that a major shift in trophic balance had occurred, with significant changes in the relative and absolute abundance of different feeding guilds. Advanced multivariate methods such as this could be employed to better understand and quantify changes to fish assemblages.

For fish farms, several studies reported increases in abundance and species richness primarily for pelagic fishes with predatory feeding habits, planktivores, and demersal species that consumed food pellets deposited under cages (Tuya et al. 2005, Valle et al. 2007, Fernandez-Jover et al. 2008). Research suggests that nutrient enrichment disproportionately increases the dominance of competitively superior species and may hence reduce diversity (Hillebrand et al. 2007). However, where nutrients are a limiting factor an increase in their availability can raise productivity, which results in increased resource heterogeneity and hence diversity (Hall et al. 2000, Arai 2001). Contaminants may even enhance diversity in some cases by reducing the abundance of competitive dominants, though this has not yet been demonstrated in fish assemblages (Rohr \& Crumrine 2005, Rohr et al. 2006, Clements \& Rohr
2009). While the average species richness response was weak, many studies reported substantial changes to the composition of fish assemblages that are not well captured or described by species richness measures. Some of these observations are discussed in more detail in 'Linking contaminant effects to fish ecology' below.

\section{Contrasting invertebrate responses}

Johnston \& Roberts (2009) conducted a recent review and meta-analysis that examined the impacts of contaminants on the diversity of marine systems. In that study it was found that many different kinds of contaminants reduced the diversity of marine assemblages in a variety of habitats. Regardless of the diversity measure employed, a reduction in diversity of 30 to $50 \%$ was observed in all study systems and contaminant classes. The Johnston \& Roberts (2009) results contrasts strongly with the overall weak species richness results observed in our study. This is likely due to the fact that the vast majority of studies (>90\%) considered in the Johnston \& Roberts (2009) review observed diversity changes in sessile invertebrate communities, while only 1 study in that review observed fish responses. The difference in observed species richness response between these 2 studies suggests that sessile invertebrate assemblages are far more responsive to contamination than fish assemblages. While few studies have contrasted diversity responses of invertebrates and fishes within the same research design, it has been demonstrated in coral reef ecosystems that the diversity response of sessile coral species is of a greater magnitude than associated fish assemblages (Fabricius et al. 2005a, Reopanichkul et al. 2009).

There are a variety of reasons why fish assemblages may be less responsive to contaminants than sessile invertebrates. Sessile invertebrates are generally considered good indicators of contamination as they are immobile and so their contaminant exposure times are predictable, many are filter feeders or live in the sediment and are thus intimately associated with contaminants in the environment, many species readily accumulate contaminants in their tissues and shells, and their diets are often relatively simple (Linton \& Warner 2003). Fish differ in some of these characteristics. While they may accumulate contaminants to a greater degree, due to their high trophic position, they can be highly mobile so direct exposure times are not certain, their diets are comparatively diverse, and they may have a higher capacity for physiological resistance and tolerance (van der Oost et al. 2003, Wirgin \& Waldman 2004). Several of these characteristics may explain why fish assemblages are less responsive to contaminants than sessile invertebrates. 


\section{Linking contaminant effects to fish ecology}

While our analysis of abundance response by broad swimming behavior and feeding guild categories did not yield significant results, several studies have suggested that fish ecological characteristics are a significant determinant of contamination response. For example, there is some evidence to suggest that fish farms disproportionately increase the abundance of pelagic fishes with predatory feeding habits and planktivores (Tuya et al. 2005, Valle et al. 2007, Fernandez-Jover et al. 2008). In other habitats and contaminant source groupings, the response of different ecological groups appears to be highly variable and at times contradictory For example, in the Khalaf \& Kochzius (2002) study, herbivores, detrivores, and planktivores experienced increased abundance and diversity in association with industrial contamination, while fish that feed on invertebrates or other fish decreased. In contrast, Otway et al. (1996b) found that sewage contamination disproportionately favored fishes feeding on invertebrates and fish. While it has been demonstrated that many contaminants bioaccumulate and biomagnify and hence disproportionately accumulate in fishes occupying higher trophic positions, this did not consistently translate into reduced abundance among the higher trophic level species examined in our review (Burger et al. 2001, van der Oost et al. 2003). Similarly, fish exhibiting different swimming habits did not appear to be strongly differentiated, despite the expectation that demersal species would be more affected than pelagic species, as contaminant concentrations in sediments are normally higher than those in the surrounding water column (Daskalakis \& O'Connor 1995, Knott et al. 2009). These findings suggest that insufficient information is available to predict the impacts of contamination based on fish ecological characteristics. It may also be the case that other ecological features, or the type of contaminant/habitat, are of greater importance when predicting the impact of contaminants on fish assemblages.

A potentially important ecological variable that was overlooked by the majority of studies in this review is how contamination impacts change at different stages of a fish's life cycle. Numerous ecotoxicological studies suggest that there is a significant development susceptibility in fish species and that eggs and larva are much more sensitive to contamination than adults (Collier et al. 1992, Waring et al. 1996, Kingsford et al. 1996b, Vetemaa et al. 1997, Ganassin et al. 1999, Hu et al. 2009). Despite the importance of contamination impacts at this stage of the life cycle, in our review only three larval fish studies were encountered and all were from a single geographic region (Gray et al. 1992, Gray 1996, 1997).

\section{Mechanisms of contaminant effects}

The majority of research addressing the effect of contamination on marine fish has focused on the chemical aspects of contamination, and a great deal of literature exists examining the presence, biomagnification, toxicology, and biomarker response of contaminants in marine fish populations (Costello \& Read 1994, Wirgin \& Waldman 1998, Austin 1999, van der Oost et al. 2003, Hylland 2006b). In this regard, the mechanisms by which contaminants affect fish populations have been fairly well investigated. Fish primarily uptake contaminants through ingestion of contaminated food particles and to a lesser extent from water that passes over the gill membranes (Dallinger et al. 1987, Hall et al. 1997). Some contaminants have also been shown to be maternally transferred to eggs and larvae (Collier et al. 1992, Hu et al. 2009). Once ingested, contaminants move through a wide variety of physiological and chemical pathways, many of which have detrimental effects for the individual. Some contaminants are readily excreted or breakdown while others are considered 'persistent' and resist decomposition in natural systems. Contaminants of this nature have the tendency to accumulate in tissues and may bioaccumulate up the food chain, increasing in concentration at higher trophic levels (Burger et al. 2001, van der Oost et al. 2003). Contaminants may affect fish populations and diversity by reducing fish health and survivorship (Robinet \& Feunteun 2002, Claireaux et al. 2004), by increasing susceptibility to disease (Arkoosh et al. 1998b), by reducing growth and reproductive success (Waring et al. 1996, Vetemaa et al. 1997), by reducing the abundance of prey species, and by increasing instances of deformity (Kingsford et al. 1996b). Ultimately, any of these mechanisms could link contaminant exposure to organismal effects and population level impacts.

In many cases, researchers have attempted to use population modeling to extrapolate observed subcellular or organismal effects to community level impacts. Numerous studies, and even a book, have been written on this subject (Barnthouse et al. 1987, 1990, Lawrence \& Hemingway 2003). While studies of this nature are a valuable addition to the literature, there is still a need for research that directly investigates and verifies the relationship between organismal effects and population level impacts. Although mechanisms of uptake, toxin persistence, and biochemical effect are extensively studied within the ecotoxicology literature, we encountered few studies (Roy et al. 2003, Claireaux et al. 2004) that linked these measures directly to ecological effects at the population or community level. 
Claireaux et al. (2004) provide a useful study in this regard. The authors utilized a multi-disciplinary approach to evaluate the effects of PAH exposure on the ecology of a common flatfish species Solea solea. They used 3 methods to evaluate the impacts at multiple levels of biological effect. This included several laboratory based toxicological experiments (assessing cellular and organ level impacts), followed by mesocosm experiments investigating fecundity and growth rates (organism levels impacts), and finally field surveys to provide field validation of toxicological experiments and to investigate population structure and abundance (population level impacts). The coupling of field surveys with experimental and mesocosm work led the authors to conclude that effects that were readily detected within individuals were progressively diminished as their research progressed towards higher organizational levels. Studies such as this could be very useful in linking the ecotoxicology/biomarker and fish ecology disciplines and would help researchers better understand the mechanisms behind ecological impacts.

Several studies have examined the development of contaminant resistance in marine and freshwater fish and some cases of resistance have been demonstrated in both laboratory and field conditions (Wirgin \& Waldman 2004, Xie \& Klerks 2004). Resistance may be due to either genetic adaptation or physiological acclimation in wild fish populations, and current research has investigated the mechanisms, costs, and persistence of toxicity resistance (Wirgin \& Waldman 2004, Xie \& Klerks 2004, Burnett et al. 2007). If the development of contaminant resistance is a regular occurrence in fish populations chronically exposed to contaminants, then impacts on abundance or diversity may be difficult to observe. However, our current understanding of the mechanisms suggests that the evolution of resistance in fish will be rare (Klerks \& Weis 1987, Klerks et al. 1997, Xie \& Klerks 2004).

\section{Knowledge gaps}

One limitation of the meta-analysis is that the scale of the studies examined varies widely. This is in part due to the nature of the meta-analysis, in that it incorporates a diverse array of experimental designs, but it is also due to the lack of knowledge of the spatial and temporal scale of contamination impacts in fish populations. In truth, the duration and distribution of impacts is not well known for a variety of contaminants and so it is difficult to assess the degree to which an analysis of these impacts should be weighted. The scale and distribution of impacts has been best studied in the fish farm literature, where several large scale studies have been produced that show the distribution of impacts over both small and large spatial scales (Dempster et al. 2009) and in terms of depth (Dempster et al. 2005). Describing the scale and distribution of impacts in this way for other contamination sources would allow us to gain a better understanding of the importance of spatial replication in investigations of this type.

In our review relatively few studies were encountered that provided both detailed environmental/water quality data and ecological monitoring data within the same research framework. Coupling fish ecology data to detailed contaminant monitoring would greatly improve our understanding of contaminant impacts and the role of specific chemicals. Studies of this nature would also allow researchers to gain a better understanding of how contaminants move through the environment and fish assemblages.

In some instances, aggregation effects (e.g. around warm water outflows from industrial facilities) may be attracting and concentrating fish without having any negative impact on their populations. Carefully designed experimental studies may be useful in untangling the relative magnitude of aggregation and nonaggregation population effects (see the discussion of the role of aggregation effects from fish farm structures and the Tuya et al. 2006 study in 'Contaminant sources' above). As discussed in 'Linking contaminant effects to fish ecology' above, future studies could examine the role of fish ecological characteristics such as life cycle stage, feeding habitats, and swimming characteristics in determining the impacts of contamination on fish assemblages. A relatively small number of studies (45) were found for the meta-analysis. This is a small sample size compared to other recent metaanalyses addressing similar topics (Micheli 1999, Johnston \& Roberts 2009). This suggests that studies investigating the effects of contamination on fish abundance and species richness are under-represented within the scientific literature. Lastly, the implementation of multivariate measurement and analysis methods (as opposed to univariate measures) would improve our understanding of changes in fish communities in the face of disturbance.

\section{CONCLUSIONS}

Anthropogenic disturbances that provide a source of contamination to marine systems appear to be affecting fish abundances and species richness. Fish farms are associated with large effects on fish abundance and diversity, and more work needs to be done to understand the ecological ramifications of these alterations. Clearly, these farms are having a major effect 
on the distribution of wild fish assemblages through the addition of large volumes of biological material into the sea. Slight negative effects on fish abundance are associated with more toxic sources of contamination such as run-off and industrial effluent, particularly in coral reefs. A greater number of more targeted field studies are needed before we can estimate the ecological impacts of toxic contaminants in these systems; however, it is likely that marine invertebrates are consistently more sensitive to contamination than fish populations. Strong trends in species richness were not observed in any categories other than fish farms; this could suggest that contaminants are not having a major impact on fish diversity. There is also significant evidence supporting the idea that features of fish assemblages other than species richness and total abundance (such as trophic balance and evenness) are being altered by contaminants. Our results suggest that some sources of contamination are having sizeable effects on fish assemblages and may be of commercial and conservation significance. Further research is needed to quantify the impacts of contamination on marine fish assemblages, to differentiate the impacts of various contaminants, and to identify taxa that are most sensitive. A better understanding of these issues will improve the monitoring and management of marine contamination, fish stocks, and biodiversity.

Acknowledgements. The authors were supported by the Australian Research Council while preparing this review through an Australian Research Fellowship and a Linkage Grant awarded to E.L.J. We thank Dr. Iain Suthers and Dr. Matt Taylor for comments which improved earlier drafts of this manuscript.

\section{LITERATURE CITED}

Aguilar C, González-Sansón G, Munkittrick KR, MacLatchy DL (2004) Fish assemblages on fringe coral reefs of the northern coast of Cuba near Havana Harbor. Ecotoxicol Environ Saf 58:126-138

Aguilar C, Gonzalez-Sanson G, Hernandez I, MacLatchy DL, Munkittrick KR (2007) Effects-based assessment in a tropical coastal system: status of bicolor damselfish (Stegastes partitus) on the north shore of Cuba. Ecotoxicol Environ Saf 67:459-471

Arai MN (2001) Pelagic coelenterates and eutrophication: a review. Hydrobiologia 451:69-87

- Araújo F, Williams W, Bailey R (2000) Fish assemblages as indicators of water quality in the middle Thames estuary, England (1980-1989). Estuaries Coasts 23:305-317

- Arkoosh MR, Casillas E, Clemons E, Kagley AN, Olson R, Reno P, Stein JE (1998a) Effect of pollution on fish diseases: potential impacts on salmonid populations. J Aquat Anim Health 10:182-190

> Arkoosh MR, Casillas E, Huffman P, Clemons E, Evered J, Stein JE, Varanasi U (1998b) Increased susceptibility of juvenile chinook salmon from a contaminated estuary to Vibrio anguillarum. Trans Am Fish Soc 127:360-374
Austin B (1999) The effects of pollution on fish health. J Appl Microbiol 85:234S-242S

Baden SP, Loo LO, Pihl L, Rosenberg R (1990) Effects of eutrophication on benthic communities including fish: Swedish west coast. Ambio 19:113-122

Barnthouse LW, Suter GW II, Rosen AE, Beauchamp JJ (1987) Estimating responses of fish populations to toxic contaminants. Environ Toxicol Chem 6:811-824

Barnthouse LW, Suter GW II, Rosen AE (1990) Risks of toxic contaminants to exploited fish populations: influence of life history, data uncertainty and exploitation intensity. Environ Toxicol Chem 9:297-311

Barry KL, Grout JA, Levings CD, Nidle BH, Piercey GE (2000) Impacts of acid mine drainage on juvenile salmonids in an estuary near Britannia Beach in Howe Sound, British Columbia. Can J Fish Aquat Sci 57:2032-2043

> Bishop MJ, Kelaher BP, Smith MP, York PH, Booth DJ (2006a) Ratio-dependent response of a temperate Australian estuarine system to sustained nitrogen loading. Oecologia 149: 701-708

> Bishop MJ, Powers SP, Porter HJ, Peterson CH (2006b) Benthic biological effects of seasonal hypoxia in a eutrophic estuary predate rapid coastal development. Estuar Coast Shelf Sci 70:415-422

Boyra A, Sanchez-Jerez P, Tuya F, Espino F, Haroun R (2004) Attraction of wild coastal fishes to an Atlantic subtropical cage fish farms, Gran Canaria, Canary Islands. Environ Biol Fishes 70:393-401

> Breitburg DL, Craig JK, Fulford RS, Rose KA and others (2009) Nutrient enrichment and fisheries exploitation: interactive effects on estuarine living resources and their management. Hydrobiologia 629:31-47

- Brewer DT, Milton DA, Fry GC, Dennis DM, Heale SDS, Venables WN (2007) Impacts of gold mine waste disposal on deepwater fish in a pristine tropical marine system. Mar Pollut Bull 54:309-321

Browman HI (1999) Negative results: the uncertain position, status and impact of negative results in marine ecology: philosophical and practical considerations. Mar Ecol Prog Ser 191:301-302

> Bundy MH, Breitburg DL, Sellner KG (2003) The responses of Patuxent River upper trophic levels to nutrient and trace element induced changes in the lower food web. Estuaries 26:365-384

Burger J, Gaines KF, Boring CS, Stephens WL, Snodgrass J, Gochfeld M (2001) Mercury and selenium in fish from the Savannah River: species, trophic level, and locational differences. Environ Res 87:108-118

Burnett KG, Bain LJ, Baldwin WS, Callard GV and others (2007) Fundulus as the premier teleost model in environmental biology: opportunities for new insights using genomics. Comp Biochem Physiol Part D Genomics Proteomics 2:257-286

Carss DN (1990) Concentrations of wild and escaped fishes immediately adjacent to fish farm cages. Aquaculture 90: $29-40$

Claireaux G, Desaunay Y, Akcha F, Auperin B and others (2004) Influence of oil exposure on the physiology and ecology of the common sole Solea solea: experimental and field approaches. Aquat Living Resour 17:335-351

Clements WH, Rohr JR (2009) Community responses to contaminants: using basic ecological principles to predict ecotoxicological effects. Environ Toxicol Chem 28:1789-1800

Collier TK, Stein JE, Sanborn HR, Hom T, Myers MS, Varanasi U (1992) Field studies of reproductive success and bioindicators of maternal contaminant exposure in 
English sole (Parophrys vetulus). Sci Total Environ 116: 169-185

Connolly RM, Jones GK (1996) Determining effects of an oil spill on fish communities in a mangrove-seagrass ecosystem in southern Australia. Aust J Ecotoxicol 2:3-15

Costello MJ, Read P (1994) Toxicity of sewage sludge to marine organisms: a review. Mar Environ Res 37:23-46

Costello MJ, Pohle G, Martin A (2001) Evaluating biodiversity in marine environmental assessments. Research and Development Monograph Series. Canadian Environmental Assessment Agency, Ottawa

Dallinger R, Prosi F, Segner H, Back H (1987) Contaminated food and uptake of heavy metals by fish: a review and a proposal for further research. Oecologia 73:91-98

> Daskalakis KD, O'Connor TP (1995) Normalization and elemental sediment contamination in the coastal United States. Environ Sci Technol 29:470-477

- Deegan LA, Wright A, Ayvazian SG, Finn JT, Golden H, Merson RR, Harrison J (2002) Nitrogen loading alters seagrass ecosystem structure and support of higher trophic levels. Aquat Cons Mar Freshw Ecosyst 12:193-212

$>$ Deegan LA, Bowen JL, Drake D, Fleeger JW and others (2007) Susceptibility of salt marshes to nutrient enrichment and predator removal. Ecol Appl 17:S42-S63

> Dempster T, Sanchez-Jerez P, Bayle-Sempere JT, GiménezCasalduero F, Valle C (2002) Attraction of wild fish to seacage fish farms in the south-western Mediterranean Sea: spatial and short-term temporal variability. Mar Ecol Prog Ser 242:237-252

Dempster T, Sanchez-Jerez P, Sempere JB, Kingsford M (2004) Extensive aggregations of wild fish at coastal seacage fish farms. Hydrobiologia 525:245-248

> Dempster T, Fernandez-Jover D, Sanchez-Jerez P, Tuya F, Bayle-Sempere J, Boyra A, Haroun RJ (2005) Vertical variability of wild fish assemblages around sea-cage fish farms: implications for management. Mar Ecol Prog Ser 304:15-29

> Dempster T, Uglem I, Sanchez-Jerez P, Fernandez-Jover D, Bayle-Sempere J, Nilsen R, Bjørn PA (2009) Coastal salmon farms attract large and persistent aggregations of wild fish: an ecosystem effect. Mar Ecol Prog Ser 385:1-14

Dempster T, Sanchez-Jerez P, Uglem I, Bjorn P (2010) Species-specific patterns of aggregation of wild fish around fish farms. Estuar Coast Shelf Sci 86(2):271-275

Dethlefsen V, Tiews K (1985) Review on the effects of pollution on marine fish life and fisheries in the North Sea. J Appl Ichthyol 1:97-118

Fabricius KE (2005b) Effects of terrestrial runoff on the ecology of corals and coral reefs: review and synthesis. Mar Pollut Bull 50:125-146

Fabricius K, De'ath G, McCook L, Turak E, Williams DM (2005a) Changes in algal, coral and fish assemblages along water quality gradients on the inshore Great Barrier Reef. Mar Pollut Bull 51:384-398

Fernandez-Jover D, Jimenez JAL, Sanchez-Jerez P, BayleSempere J, Casalduero FG, Lopez FJM, Dempster T (2007) Changes in body condition and fatty acid composition of wild Mediterranean horse mackerel (Trachurus mediterraneus, Steindachner, 1868) associated to sea cage fish farms. Mar Environ Res 63:1-18

Fernandez-Jover D, Sanchez-Jerez P, Bayle-Sempere JT, Valle C, Dempster T (2008) Seasonal patterns and diets of wild fish assemblages associated with Mediterranean coastal fish farms. ICES J Mar Sci 65:1153-1160

Frank KT, Petrie B, Choi JS, Leggett WC (2005) Trophic cascades in a formerly cod-dominated ecosystem. Science
308:1621-1623

Ganassin RC, Sanders SM, Kennedy CJ, Joyce EM, Bols NC (1999) Development and characterization of a cell line from Pacific herring, Clupea harengus pallasi, sensitive to both naphthalene cytotoxicity and infection by viral hemorrhagic septicemia virus. Cell Biol Toxicol 15: 299-309

Gray CA (1996) Intrusions of surface sewage plumes into continental shelf waters: interactions with larval and presettlement juvenile fishes. Mar Ecol Prog Ser 139:31-45

> Gray CA (1997) Field assessment of numerical impacts of coastal sewage disposal on fish larvae relative to natural variability. Environ Biol Fishes 50:415-434

> Gray CA, Otway NM, Laurenson FA, Miskiewicz AG, Pethebridge RL (1992) Distribution and abundance of marine fish larvae in relation to effluent plumes from sewage outfalls and depth of water. Mar Biol 113:549-559

Grigg RW (1994) Effects of sewage discharge, fishing pressure and habitat complexity on coral ecosystems and reef fishes in Hawaii. Mar Ecol Prog Ser 103:25-34

> Guidetti P, Terlizzi A, Fraschetti S, Boero F (2003) Changes in Mediterranean rocky-reef fish assemblages exposed to sewage pollution. Mar Ecol Prog Ser 253:269-278

Hall BD, Bodaly RA, Fudge RJP, Rudd JWM, Rosenberg DM (1997) Food as the dominant pathway of methylmercury uptake by fish. Water Air Soil Pollut 100:13-24

> Hall SJ, Gray SA, Hammett ZL (2000) Biodiversity-productivity relations: an experimental evaluation of mechanisms. Oecologia 122:545-555

Hedges LV, Gurevitch J, Curtis PS (1999) The meta-analysis of response ratios in experimental ecology. Ecology 80: $1150-1156$

Hillebrand H, Gruner DS, Borer ET, Bracken MES and others (2007) Consumer versus resource control of producer diversity depends on ecosystem type and producer community structure. Proc Natl Acad Sci USA 104:10904-10909

- Hoisington G, Lowe CG (2005) Abundance and distribution of the round stingray, Urobatis halleri, near a heated effluent outfall. Mar Environ Res 60:437-453

> Hu JY, Zhang ZB, Wei QW, Zhen HJ and others (2009) Malformations of the endangered Chinese sturgeon, Acipenser sinensis, and its causal agent. Proc Natl Acad Sci USA 106:9339-9344

> Hylland K, Beyer J, Berntssen M, Klungsoyr J, Lang T, Balk L (2006a) May organic pollutants affect fish populations in the North Sea? J Toxicol Environ Health A 69:125-138

Hylland K (2006b) Biological effects in the management of chemicals in the marine environment. Mar Pollut Bull 53: 614-619

- Islam MS, Tanaka M (2004) Impacts of pollution on coastal and marine ecosystems including coastal and marine fisheries and approach for management: a review and synthesis. Mar Pollut Bull 48:624-649

Jacobsson A, Neuman E (1991) Fish recruitment around a petrochemical centre in the North Sea. Mar Pollut Bull 22: 269-272

Jiao Y (2009) Regime shift in marine ecosystems and implications for fisheries management, a review. Rev Fish Biol Fish 19:177-191

> Johnston EL, Roberts DA (2009) Contaminants reduce the richness and evenness of marine communities: a review and meta-analysis. Environ Pollut 157:1745-1752

> Jones JC, Reynolds JD (1997) Effects of pollution on reproductive behaviour of fishes. Rev Fish Biol Fish 7:463-491

> Jones GK, Baker JL, Edyvane K, Wright GJ (1996) Nearshore fish community of the Port River-Barker Inlet Estuary, 
South Australia. I. Effect of thermal effluent on the fish community structure, and distribution and growth of economically important fish species. Mar Freshw Res 47: 785-799

Karas P, Neuman E, Sandstrom O (1991) Effects of a pulp mill effluent on the population dynamics of perch, Perca-fluviatilis. Can J Fish Aquat Sci 48:28-34

Khalaf MA, Kochzius M (2002) Changes in trophic community structure of shore fishes at an industrial site in the Gulf of Aqaba, Red Sea. Mar Ecol Prog Ser 239:287-299

Kingsford MJ, Suthers IM, Gray CA (1996a) Exposure to sewage plumes and the incidence of deformities in larval fishes. Mar Pollut Bull 33:201-212

Kingsford MJ, Suthers IM, Gray CA (1996b) Exposure to sewage plumes and the incidence of deformities in larval fishes. Mar Pollut Bull 33:201-212

Klerks PL, Weis JS (1987) Genetic adaptation to heavy metals in aquatic organisms: a review. Environ Pollut 45:173-205

Klerks PL, Leberg PL, Lance RF, McMillin DJ, Means JC (1997) Lack of development of pollutant-resistance or genetic differentiation in darter gobies (Gobionellus boleosoma) inhabiting a produced-water discharge site. Mar Environ Res 44:377-395

Knott NA, Aulbury J, Brown T, Johnston EL (2009) Contemporary ecological threats from historical pollution sources: impacts of large-scale resuspension of contaminated sediments on sessile invertebrate recruitment. J Appl Ecol 46: $770-781$

Landner L, Grahn O, Hardig J, Lehtinen KJ, Monfelt C, Tana $\mathrm{J}$ (1994) A field study of environmental impacts at a bleached kraft pulp mill site on the Baltic Sea coast. Ecotoxicol Environ Saf 27:128-157

Lawrence AJ, Hemingway KL (eds) (2003) Effects of pollution on fish: molecular effects and population responses. Blackwell Science, Oxford

Linton DM, Warner GF (2003) Biological indicators in the Caribbean coastal zone and their role in integrated coastal management. Ocean Coast Manag 46:261-276

> Machias A, Karakassis I, Labropoulou M, Somarakis S, Papadopoulou KN, Papaconstantinou C (2004) Changes in wild fish assemblages after the establishment of a fish farming zone in an oligotrophic marine ecosystem. Estuar Coast Shelf Sci 60:771-779

Machias A, Karakassis I, Giannoulaki M, Papadopoulou KN, Smith CJ, Somarakis S (2005) Response of demersal fish communities to the presence of fish farms. Mar Ecol Prog Ser 288:241-250

> Machias A, Giannoulaki M, Somarakis S, Maravelias CD and others (2006) Fish farming effects on local fisheries landings in oligotrophic seas. Aquaculture 261:809-816

Micheli F (1999) Eutrophication, fisheries, and consumerresource dynamics in marine pelagic ecosystems. Science 285:1396-1398

Murphy CA, Rose KA, Alvarez M, Fuiman LA (2008) Modeling larval fish behavior: scaling the sublethal effects of methylmercury to population-relevant endpoints. Aquat Toxicol 86:470-484

- Nagai T (2003) Recovery of fish stocks in the Seto Inland Sea. Mar Pollut Bull 47:126-131

$>$ Nixon S, Buckley B (2002) 'A strikingly rich zone' — nutrient enrichment and secondary production in coastal marine ecosystems. Estuaries Coasts 25:782-796

> Oakes CT, Pondella DJ (2009) The value of a net-cage as a fish aggregating device in southern California. J World Aquacult Soc 40:1-21

Oczkowski A, Nixon S (2008) Increasing nutrient concentra- tions and the rise and fall of a coastal fishery; a review of data from the Nile Delta, Egypt. Estuar Coast Shelf Sci 77: 309-319

> Otway NM, Gray CA, Craig JR, McVea TA, Ling JE (1996a) Assessing the impacts of deepwater sewage outfalls on spatially- and temporally-variable marine communities. Mar Environ Res 41:45-71

Otway NM, Sullings DJ, Lenehan NW (1996b) Trophicallybased assessment of the impacts of deepwater sewage disposal on a demersal fish community. Environ Biol Fishes 46:167-183

Pastorok RA, Bilyard GR (1985) Effects of sewage pollution on coral reef communities. Mar Ecol Prog Ser 21:175-189

Pauly D, Christensen V, Guenette S, Pitcher TJ and others (2002) Towards sustainability in world fisheries. Nature 418:689-695

Perry AL, Low PJ, Ellis JR, Reynolds JD (2005) Climate change and distribution shifts in marine fishes. Science 308:1912-1915

Reopanichkul P, Schlacher TA, Carter RW, Worachananant S (2009) Sewage impacts coral reefs at multiple levels of ecological organization. Mar Pollut Bull 58:1356-1362

- Ribeiro J, Monteiro CC, Monteiro P, Bentes L and others (2008) Long-term changes in fish communities of the Ria Formosa coastal lagoon (southern Portugal) based on two studies made 20 years apart. Estuar Coast Shelf Sci 76: $57-68$

Roberts DA, Johnston EL, Knott NA (2010) Impacts of desalination plant discharges on the marine environment: a critical review of published studies. Water Res 44: $5117-5128$

- Robinet TT, Feunteun EE (2002) Sublethal effects of exposure to chemical compounds: a cause for the decline in Atlantic eels? Ecotoxicology 11:265-277

Rohr JR, Crumrine PW (2005) Effects of an herbicide and an insecticide on pond community structure and processes. Ecol Appl 15:1135-1147

> Rohr JR, Kerby JL, Sih A (2006) Community ecology as a framework for predicting contaminant effects. Trends Ecol Evol 21:606-613

Rose KA (2000) Why are quantitative relationships between environmental quality and fish populations so elusive? Ecol Appl 10:367-385

Roy LA, Armstrong JL, Sakamoto K, Steinert S and others (2003) The relationships of biochemical endpoints to histopathology and population metrics in feral flatfish species collected near the municipal wastewater outfall of Orange County, California, USA. Environ Toxicol Chem 22:1309-1317

> Russo AR (1982) Temporal changes in fish community structure near a sewage ocean outfall, Mokapu, Oahu, Hawaii. Mar Environ Res 6:83-98

Sandström O (1994) Incomplete recovery in a coastal fish community exposed to effluent from a modernized Swedish bleached kraft mill. Can J Fish Aquat Sci 51: 2195-2202

> Sandström O, Neuman E (2003) Long-term development in a Baltic fish community exposed to bleached pulp mill effluent. Aquat Ecol 37:267-276

Smith AK, Suthers IM (1999b) Effects of sewage effluent discharge on the abundance, condition and mortality of hulafish, Trachinops taeniatus (Plesiopidae). Environ Pollut 106:97-106

Smith AK, Ajani PA, Roberts DE (1999a) Spatial and temporal variation in fish assemblages exposed to sewage and implications for management. Mar Environ Res 47:241-260 
Tober JD, Griffin MPA, Valiela I (2000) Growth and abundance of Fundulus heteroclitus and Menidia menidia in estuaries of Waquoit Bay, Massachusetts exposed to different rates of nitrogen loading. Aquat Ecol 34: 299-306

Tuya F, Boyra A, Sanchez-Jerez P, Haroun RJ (2005) Multivariate analysis of the bentho-demersal ichthyofauna along soft bottoms of the eastern Atlantic: comparison between unvegetated substrates, seagrass meadows and sandy bottoms beneath sea-cage fish farms. Mar Biol 147: 1229-1237

Tuya F, Sanchez-Jerez P, Dempster T, Boyra A, Haroun RJ (2006) Changes in demersal wild fish aggregations beneath a sea-cage fish farm after the cessation of farming. J Fish Biol 69:682-697

Valle C, Bayle-Sempere JT, Dempster T, Sanchez-Jerez P, Giménez-Casalduero F (2007) Temporal variability of wild fish assemblages associated with a sea-cage fish farm in the south-western Mediterranean Sea. Estuar Coast Shelf Sci 72:299-307

van der Oost R, Beyer J, Vermeulen NPE (2003) Fish bioaccumulation and biomarkers in environmental risk assessment: a review. Environ Toxicol Pharmacol 13:57-149

Vetemaa M, Sandström O, Förlin L (1997) Chemical industry effluent impacts on reproduction and biochemistry in a North Sea population of viviparous blenny (Zoarces viviparus). J Aquat Ecosyst Stress Recovery 6:33-41

> Waring CP, Stagg RM, Fretwell K, McLay HA, Costello MJ (1996) The impact of sewage sludge exposure on the reproduction of the sand goby, Pomatoschistus minutus. Environ Pollut 93:17-25

Washington HG (1984) Diversity, biotic and similarity indices: a review with special relevance to aquatic ecosystems. Water Res 18:653-694

Wirgin I, Waldman JR (1998) Altered gene expression and genetic damage in North American fish populations. Mutat Res 399:193-219

Wirgin I, Waldman JR (2004) Resistance to contaminants in North American fish populations. Mutation Research Fundamental and Molecular Mechanisms of Mutagenesis 552: 73-100

Wu RSS, Lam KS, MacKay DW, Lau TC, Yam V (1994) Impact of marine fish farming on water quality and bottom sediment: a case study in the sub-tropical environment. Mar Environ Res 38:115-145

Xie L, Klerks PL (2004) Changes in cadmium accumulation as a mechanism for cadmium resistance in the least killifish Heterandria formosa. Aquat Toxicol 66:73-81

Appendix 1. Meta-analysis studies

\begin{tabular}{|c|c|c|c|c|c|}
\hline $\begin{array}{l}\text { Abundance: } \\
\text { direction } \\
\text { of impact }\end{array}$ & $\begin{array}{l}\text { Richness: } \\
\text { direction } \\
\text { of impact }\end{array}$ & $\begin{array}{l}\text { Contaminant } \\
\text { source }\end{array}$ & $\begin{array}{l}\text { Study } \\
\text { system }\end{array}$ & $\begin{array}{l}\text { Research } \\
\text { approach }\end{array}$ & Source \\
\hline No data & Increase & Sewage & Coral reef & Survey & Aguilar et al. (2004) \\
\hline Decrease & No data & Sewage & Coral reef & Survey & Aguilar et al. (2007) \\
\hline Decrease & Decrease & Sewage & Vegetated habitats & Survey & Araújo et al. (2000) \\
\hline Decrease & No data & Run-off & Bare sediment & Survey & Baden et al. (1990) \\
\hline Decrease & No data & Industrial effluent & Bare sediment & Survey & Barry et al. (2000) \\
\hline Increase & No data & Sewage & Bare sediment & Survey & Bishop et al. (2006a) \\
\hline Increase & No data & Fish farm & Vegetated habitats & Survey & Boyra et al. (2004) \\
\hline Decrease & No data & Industrial effluent & Coral reef & Survey & Brewer et al. (2007) \\
\hline No change & No data & Run-off & Vegetated habitats & Field experiment & Bundy et al. (2003) \\
\hline Increase & Increase & Fish farm & Bare sediment & Survey & Carss (1990) \\
\hline No change & No data & Industrial effluent & Bare sediment & Survey & Claireaux et al. (2004) \\
\hline No change & No data & Industrial effluent & Vegetated habitats & Survey & Connolly \& Jones (1996) \\
\hline Decrease & Decrease & Run-off & Vegetated habitats & Field experiment & Deegan et al. (2002) \\
\hline Increase & Increase & Fish farm & Bare sediment & Survey & Dempster et al. (2002) \\
\hline Increase & No data & Fish farm & Bare sediment & Survey & Dempster et al. (2004) \\
\hline Increase & No data & Fish farm & Bare sediment & Survey & Dempster et al. (2004) \\
\hline Decrease & Decrease & Run-off & Coral reef & Survey & Fabricius et al. (2005a) \\
\hline Increase & Increase & Sewage & Rocky bottom and rocky reef & Survey & Gray (1996) \\
\hline Decrease & Decrease & Sewage & Rocky bottom and rocky reef & Survey & Gray et al. (1992) \\
\hline Increase & Increase & Sewage & Coral reef & Survey & Grigg (1994) \\
\hline Increase & No data & Sewage & Rocky bottom and rocky reef & Survey & Guidetti et al. (2003) \\
\hline Increase & No data & Industrial effluent & Bare sediment & Survey & Hoisington \& Lowe (2005) \\
\hline Decrease & No data & Industrial effluent & Bare sediment & Survey & Jacobsson \& Neuman (1991) \\
\hline Increase & Decrease & Industrial effluent & Bare sediment & Survey & Jones et al. (1996) \\
\hline Decrease & No data & Industrial effluent & Poorly defined & Survey & Karas et al. (1991) \\
\hline Decrease & No change & Industrial effluent & Coral reef & Survey & Khalaf \& Kochzius (2002) \\
\hline Decrease & Increase & Industrial effluent & Bare sediment & Survey & Landner et al. (1994) \\
\hline Increase & No data & Fish farm & Bare sediment & Survey & Machias et al. (2004) \\
\hline Increase & No data & Fish farm & Bare sediment & Survey & Machias et al. (2005) \\
\hline
\end{tabular}


Appendix 1 (continued)

\begin{tabular}{|c|c|c|c|c|c|}
\hline $\begin{array}{l}\text { Abundance: } \\
\text { direction } \\
\text { of impact }\end{array}$ & $\begin{array}{l}\text { Richness: } \\
\text { direction } \\
\text { of impact }\end{array}$ & $\begin{array}{c}\text { Contaminant } \\
\text { source }\end{array}$ & $\begin{array}{l}\text { Study } \\
\text { system }\end{array}$ & $\begin{array}{l}\text { Research } \\
\text { approach }\end{array}$ & Source \\
\hline Decrease & No data & Run-off & Bare sediment & Fisheries catch study & Nagai (2003) \\
\hline No change & No data & Fish farm & Rocky bottom and rocky reef & Survey & Oakes \& Pondella (2009) \\
\hline Increase & No data & Run-off & Vegetated habitats & Fisheries catch study & Oczkowski \& Nixon (2008) \\
\hline Increase & Increase & Sewage & Rocky bottom and rocky reef & Survey & Otway et al. (1996a) \\
\hline Increase & Increase & Sewage & Bare sediment & Survey & Otway et al. (1996b) \\
\hline Decrease & No data & Sewage & Coral reef & Survey & Reopanichkul et al. (2009) \\
\hline Increase & Decrease & Sewage & Vegetated habitats & Survey & Ribeiro et al. (2008) \\
\hline Decrease & No data & Sewage & Bare sediment & Survey & Roy et al. (2003) \\
\hline Increase & No data & Sewage & Bare sediment & Survey & Russo (1982) \\
\hline Decrease & Decrease & Industrial effluent & Poorly defined & Survey & Sandström \& Neuman (2003) \\
\hline Decrease & No data & Industrial effluent & Poorly defined & Survey & Sandström (1994) \\
\hline Decrease & No data & Sewage & Rocky bottom and rocky reef & Survey & Smith \& Suthers (1999) \\
\hline Decrease & Decrease & Sewage & Rocky bottom and rocky reef & Survey & Smith et al. (1999) \\
\hline Increase & No data & Run-off & Vegetated habitats & Survey & Tober et al. (2000) \\
\hline Increase & Increase & Fish farm & Bare sediment & Survey & Tuya et al. (2005) \\
\hline Increase & Increase & Fish farm & Bare sediment & Survey & Valle et al. (2007) \\
\hline
\end{tabular}

Editorial responsibility: Jana Davis, Annapolis, Maryland, USA
Submitted: April 1, 2010; Accepted: September 28, 2010 Proofs received from author(s): December 8, 2010 